\title{
PENERAPAN METODE TOTAL PHYSICAL RESPONSE (TPR) \\ DALAM PEMBELAJARAN MAHARAH KITABAH
}

Ahmad Syagif HM, M.Pd., dan Anwar Sadat, M, Pd.I

(Dosen STIT Sunan Giri Bima dan IAI Muhammadiyah Bima)

(4gyptik@gmail.com, anwarbinmalik18@gmail.com)

$$
\text { الملخص }
$$

إن مهارة الكتابة لها دور مهم في الحياة الإنســانية. وفي حجرة الدراســـة تعتبر الكتابة من أهم مهارة اللغـة كهـدف رئيسـي من أهـداف تعليم اللغـة الأجنبيـة. إضـــافـة إلى ذلك لهـذه المهارة خصـــائص تتميز بها عن المهارات الأخرى، وهـذه طبعـا تؤدى إلى الاختلاف في اختيـار طربقــة تدربسـها. لذلك، على المدرسين أن يختار طربقة تدربس الكتابة الفعالة المناسبـة لتنمية كفاءة الدارسـيـن في هذه المهارة مثها طر:قـة الاســتجابة العضـــوبة الكاملة . إن هذه الطربقة حقيقة التطوير والتوسـيع من نظرية التعليم على اسـاس النشـاط ـ أول من عرف ويشـر هذه الطربقة هو جـامس آشــر عـالم أمرئي في علم النفس. وهي طربقـة التى تبنى على مجموعـة من الأوامر والنشاط الحركي. استند هذه الطر:قة إلى نظرية التعلم للمدخل الطبيعي الذى أعطى اهتماما

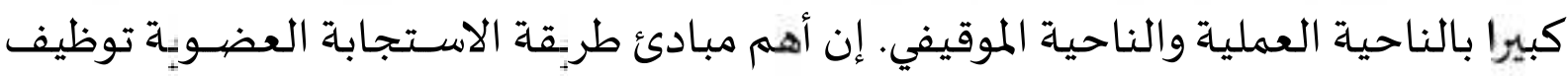
النشـاط الحركي لتنمية قدرة الطلاب على الفهم. وعلى هذا، قدم آشـر مبادئ أسـاسـية تجعل الدارسين لديهم تقدم الفهم للغة أو ما يسمى بالمدخل الفهيه، وأولها أن في تعليم اللغة القدرة على الفههم تسـبق القدرة الإنتاجية. و ثانيها تأخير تعليم الكلام بعد أن وصـل الطلاب إلى تقدم الفههم، وثالثها المهارة تكتسـبـ من الاســتماع الذى يوصــلها إلى المهارة الأخرى، ور ابعها يفضـل التعليم الجانب المعنوي عن الجانب الشكالي، وخامسها يقصر التعليم جو التوتر عند الطلاب.

\section{كلمة البحث : مهارة الكتابة، اللغة العريية، طريقة الاستجابة العضوية الكاملة}

Maharah Kitabah (keterampilan menulis) memiliki peran signifikan dalam kehidupan manusia. Di lembaga pendidikan pun, penguasaan keterampilan menulis menjadi salah satu tujuan utama dalam pembelajaran bahasa asing. Sebagai catatan, keterampilan menulis memiliki karakteristik khusus dibanding keterampilan berbahasa lainnya yang berimplikasi pada metode pengajarannya. Karena itu setiap pendidik perlu mencari metode pembelajaran menulis yang efektif untuk meningkatkan keterampilan peserta didiknya, dan salah satunya adalah metode Total Physical Response (Respon Fisik Sempurna) atau dikenal dengan TPR. Metode TPR dikembangkan oleh seorang psikolog Amerika James Asher pada dekade 60-an. Metode ini merupakan salah satu metode pembelajaran untuk bahasa asing yang berlandaskan pada teori 
Action Based Teaching dan pendekatan naturalistik humanistik, yang dikonstruksi oleh pola pemberian instruksi dan gerakan fisik serta memberikan perhatian besar pada aspek praktis dan situasi pembelajaran. Dengan kata lain metode ini memberikan penekanan pada pemahaman (comprehension) melalui penggunaan gerakan fisik dalam mengajar bahasa asing pada level pengenalan (introductory level). Metode ini memiliki prinsip, pertama, kemampuan pemahaman diikuti dengan keahlian produktif dalam belajar bahasa (lisan dan tulisan), kedua, menunda pengajaran berbicara sebelum pemahaman anak sudah terbangun, ketiga, keterampilan berbahasa didapat melalui mendengar yang ditransfer kepada keahlian lain (berbicara, membaca, dan menulis), keempat, Pengajaran harus menekankan arti daripada bentuk, dan kelima, pengajaran harus meminimalkan kadar stres pembelajar.

\section{Kata Kunci: Maharah Kitabah, Keterampilan Menulis, Bahasa Arab, TPR}

\section{A. PENDAHULUAN}

Bahasa adalah suatu sistim dari suara, kata, pola yang digunakan oleh manusia untuk berkomunikasi melalui pikiran dan perasaan. Melalui bahasa manusia mengemukakan pikiran dan gagasannya baik melalui bahasa lisan maupun bahasa tulisan. Setiap bahasa pasti memiliki komponen-komponen yang sama yaitu, bunyi bahasa, kosa kata, struktur tata bahasa, dan makna. ${ }^{1}$

Seperti halnya berbicara, menulis mengandalkan kemampuan bahasa yang bersifat aktif-produktif. ${ }^{2}$ Keduanya merupakan usaha untuk mengungkapkan pikiran dan perasaan yang ada pada diri seseorang pemakai bahasa melelui bahasa. Perbedaannya terletak pada cara yang digunakan untuk mengungkapkannya. Selagi pikiran dan perasaan dalam berbicara diungkapkan secara lisan, penyampaian pesan dalam menulis dilakukan secara tertulis. Perbedaan cara menyampaikan pesan itu ditandai dengan ciri-ciri yang berbeda dan tuntutan yang berbeda pula dalam penggunaannya. Perbedaan-perbedaan itu pada gilirannya tercermin pula pada bagaimana mengajarkannya. ${ }^{3}$

Dalam penggunaan bahasa sehari-hari, berbicara pada umumnya dilakukan dalam jumlah dan frekuensi yang lebih besar daripada menulis. Banyak hal yang terjadi dan dialami oleh seorang pemakai bahasa, yang perlu diungkapkan secara lisan kepada orang lain. Ada kalanya pengungkapan pikiran dan perasaan yang dialami itu dilakukan tanpa

\footnotetext{
${ }^{1}$ Hilmi Khalil, Muqaddimah li Dirasah 'Ilmi al Lughah, (Kairo: Dar al Ma'rifah al Jama'iyyah, 2000), 36.

${ }^{2}$ Hamadah Ibrahim, Al Ittijahat Al Mu'ashirah fi Tadris Al Lughah Al 'Arabiyah wa Al Lughah Al Hayyah Al Ukhra lighair Al Nathiqin biha, (Kairo: Dar Al Fikr Al 'Arabiy, 1987), 249.

${ }^{3}$ M. Soenardi Djiwandono, Tes Bahasa dalam Pengajaran, (Bandung: Penerbit ITB, 1996), 43.
} 
banyak waktu untuk mempersiapkan diri secara cukup, dan mengatur apa yang ingin diungkapkan secara rapi. Tanggapan terhadap apa yang diungkapkan pun dapat segera diperoleh dari orang lain yang merupakan lawan bicara. Oleh karena itu selain frekuensinya yang tinggi, berbicara pada umumnya juga terjadi secara spontan, tanpa banyak kesempatan untuk memperhatikan berbagai kaidah penggunaan bahasa secara semestinya. Hal ini dapat dilihat baik pada penggunaan bahasa pertama atau bahkan pada bahasa kedua.

Dengan frekuensi yang tinggi dan penggunaan yang spontan dengan tidak terencana semacam itu, titik berat berbicara terletak lebih pada isi pesan yang perlu disampaikan, daripada aspek-aspek kebahasaan seperti pemilihan kata dan susunan kalimat. Pesan yang kurang jelas atau kurang lengkap tersampaikan melalui berbicara dapat dengan mudah diulangi, dilengkapi, atau dikoreksi dengan ungkapan-ungkapan tambahan.

Berbeda halnya dengan penggunaan bahasa secara tertulis. Dalam mengungkapkan diri secara tertulis, seorang pemakai bahasa memiliki lebih kesempatan untuk mempersiapkan dan mengatur diri, baik dalam hal apa yang ingin diungkapkan, maupun bagaimana cara mengungkapkannya. Pesan yang perlu diungkapkan dapat dipilih secara cermat dan disusun secara sistematis, agar bila diungkapkan secara tertulis mudah dipahami secara tepat. Demikian pula dengan pemilihan kata-kata, dan penyusunannya dalam bentuk wacana, yang dapat dilakukan sesuai dengan kaidah-kaidah bahasa yang baik dan benar. Jelaslah dalam menulis, unsur kebahasaan meruakan aspek penting yang perlu dicermati, disamping isi pesan yang diungkapkan yang merupakan inti dari hakikatnya sebagai bentuk penggunaan bahasa yang aktif-produktif.

Namun kenyataannya, dalam pembelajaran bahasa asing khususnya bahasa Arab, perhatian terhadap keterampilan menulis (kitabah) dapat dikatakan kurang maksimal. Hal tersebut diperparah lagi dengan kurangnya perhatian serius dari guru-gurunya, waktu belajar yang terbatas, serta metode pembelajaran yang kurang inovatif sehingga mempengaruhi motivasi pembelajaranya. ${ }^{4} \mathrm{Hal}$ ini dapat dilihat pada berbagai jenjang pendidikan di Sekolah maupun madrasah. Sebagian besar pendidik lebih menekankan pengajaran keterampilan membaca serta tata bahasa (qawa'id), sehingga terkesan lebih

\footnotetext{
${ }^{4}$ Mahmud Kamil Naqah, Thara'iq tadris al-Lugah al-'Arabiyyah lighair al-Nathiqin biha, (Rabat: ISESCO, 2003), 231.
} 
menekankan ilmu bahasa, bukan bagaimana berbahasa. Karena itu dibutuhkan upaya serius untuk mengatasi hal tersebut.

Ketercapaian tujuan yang berkaitan dengan kegiatan pembelajaran ditentukan oleh interaksi pembelajaran yang efektif antara guru dan murid. ${ }^{5}$ Ada beberapa faktor yang mempengaruhi hal tersebut antara lain, siswa, pengajar, alat, dan metode pembelajaran yang tepat demikian pula dalam kegiatan pembelajaran menulis. Hal tersebut akan mewarnai keberhasilan pembelajaran sesuai dengan tujuan yang telah ditetapkan. Faktor pengajar dan metode pembelajaran yang dipilih dalam menumbuhkan dan mengembangkan keterampilan menulis tidak dapat diabaikan begitu saja.

Badudu menyatakan bahwa kesalahan yang tampak dalam pembelajaran bahasa adalah pengajar yang terlalu banyak menyuapi tetapi kurang melibatkan siswa aktif belajar. ${ }^{6}$ Seorang pengajar merupakan faktor penting dalam lingkungan belajar dan kehidupan siswa. Pengajar juga berperan sebagai rekan belajar, model, pembimbing, fasilitator, dan pendorong kesuksesan siswa sekaligus sebagai evaluator yang perlu berusaha terus mengembangkan kemampuan siswa dalam keterampilan menulis. ${ }^{7}$ Dalam kenyataannya, tidak sedikit temuan di lapangan yang menunjukkan bahwa keterampilan siswa dalam menulis relatif masih rendah. Sebagian besar dari mereka belum mampu menuangkan ide secara tertulis dengan baik dan benar, baik berdasarkan apa yang mereka lihat maupun yang mereka dengar. Hal tersebut mengisyaratkan keterampilan menulis masih perlu ditingkatkan. Metode pembelajaran yang digunakan juga masih perlu diupayakan agar lebih bervariasi dan bermakna.

Berdasarkan hal tersebut, kegiatan pembelajaran menulis perlu dilaksanakan dengan pemilihan metode pembelajaran yang tepat. Pemilihan metode pembelajaran yang tepat sangat dibutuhkan dalam proses belajar mengajar agar tujuan pembelajaran dapat dicapai sesuai dengan yang diharapkan. Metode yang tepat dapat memenuhi tuntutan belajar peserta didik sehingga memungkinkan potensinya berkembang secara optimal, baik potensi emosional, mental intelektual, maupun psikomotornya. ${ }^{8}$ Metode Total Physical

\footnotetext{
5 Ahmad Ibrahim Qindil, Ususu Thuruq Al Tadris, (Dar Al Kutub, 1995), 161.

${ }^{6}$ Yus Badudu, Mahir Berbahasa Indonesia, (Jakarta: Gramedia, 1990), 131.

7 S. Riyono, Teknik Belajar Mengajar dalam CBSA, (Jakarta: Rineka Cipta1991), 5.

${ }^{8}$ Effendi, Ahmad FuadMetodologi Pengajaran Bahasa Arab, (Malang: Misykat, 2005), 37.
} 
Response (TPR) merupakan salah satu metode alternatif yang dapat digunakan dan diharapkan dapat memotivasi dan membantu siswa dalam meningkatkan keterampilan menulis, khususnya bagi pembelajar pemula.

\section{TINJAUAN TENTANG MAHARAH KITABAH}

\section{Maharah Kitabah dan Karakteristiknya}

Jika kita ingin mempelajari sebuah bahasa, maka kita harus mempelajarinya secara utuh. Hal ini berlaku dalam mempelajari baik bahasa pertama maupun bahasa kedua. Belajar bahasa Arab misalnya, berarti ia harus belajar mendengarkan (istima'), berbicara (kalam), membaca (qira'ah), dan menulis (kitabah) dalam bahasa Arab. Sebagian kalangan memaknai menulis hanya sebatas aktifitas copying dan spelling. 9 Ada pula yang mamaknainya sebagai sebuah keterampilan berbahasa yang terpadu, yang ditujukan untuk menghasilkan sesuatu yang disebut tulisan untuk menyampaikan informasi kepada orang lain serta sebagai alat dokumentasi dari masa kemasa. 10

Sama dengan maharah al kalam (keterampilan berbicara), Menulis pada dasarnya merupakan suatu kegiatan yang produktif dan ekspresif. Namun demikian, kegiatan berbicara lebih dominan dilakukan dalam aktifitas harian dibanding menulis. Bahkan sebagian besar aktifitas berbicara dilakukan secara spontan dan tidak terlalu terikat dengan aspek ketatabahasaan karena lebih memprioritaskan sampainya pesan kepada lawan bicara. Hal inilah yang tidak bisa disamakan dengan menulis. Sebelum menulis, lebih banyak kesempatan untuk mempersiapkan dan mendesain redaksi tulisan yang akan dituangkan, baik dari segi pilihan kata, kaidah kebahasaan, dan substansi pesan itu sendiri. 11

Dalam kegiatan menulis ini seorang penulis harus terampil memanfaatkan grafologi, struktur bahasa, dan kosakata. Keterampilan menulis digunakan untuk mencatat, merekam, meyakinkan, melaporkan, menginformasikan, dan

\footnotetext{
${ }^{9}$ Rusdy Ahmad Tu'aimah, Ta'lim al-'Arabiyyah lighair al-Nathiqin biha Manahijuhu wa Asalibuhu. (Rabat: ISESCO, 1989), 187.

${ }^{10}$ Al Syantha, Muhammad Shalih, Al Maharat Al Lughawiyyah Madkhal ila Khasha'isi Al Lughah Al 'Arabiyyah wa Fununiha, (Ha'il : Dar Al Andalus li Al Nasyr wa Al Tauzi', 1996), 205.

11 Rusydi Ahmad Thu'aimah dan Mahmud Kamil Naqqah, Thara'iq Tadris Al Lughah Al 'Arabiyyah Li Ghair An Nathiqin Biha, (Rabat: Isesco, 2003), 202.
} 
mempengaruhi pembaca. Maksud dan tujuan seperti itu hanya dapat dicapai dengan baik oleh para pembelajar yang dapat menyusun dan merangkai jalan pikiran dan mengemukakannya secara tertulis dengan jelas, lancar, dan komunikatif. Kejelasan ini bergantung pada pikiran, organisasi, pemakaian dan pemilihan kata, dan struktur kalimat Karena itu, tidak heran jika ada kalangan yang menyatakan bahwa keterampilan menulis adalah yang paling sukar dibanding tiga keterampilan berbahasa lainnya. ${ }^{12}$

Sekurang-kurangnya, ada tiga komponen yang tergabung dalam perbuatan menulis, yaitu: pertama; penguasaan bahasa tulis, yang akan berfungsi sebagai media tulisan, meliputi: kosakata, struktur kalimat, paragraf, ejaan, pragmatik, dan sebagainya; kedua; penguasaan isi karangan sesuai dengan topik yang akan ditulis; dan ketiga; penguasaan tentang jenis-jenis tulisan, yaitu bagaimana merangkai isi tulisan dengan menggunakan bahasa tulis sehingga membentuk sebuah komposisi yang diinginkan, seperti esai, artikel, cerita pendek, makalah, dan sebagainya.

Tidak ada waktu yang tidak tepat untuk memulai menulis. Artinya, kapan pun, di mana pun, dan dalam situasi yang bagaimana pun seorang penutur asing yang belajar di Indonesia dapat melakukannya. Ketakutan akan kegagalan bukanlah penyebab yang harus dipertahankan. Itulah salah satu kiat, teknik, dan strategi yang ditawarkan oleh David Nunan ${ }^{13}$ dalam bukunya Language Teaching Methodology. Dia menawarkan suatu konsep pengembangan keterampilan menulis yang meliputi: pertama; perbedaan antara bahasa lisan dan bahasa tulisan, kedua; menulis sebagai suatu proses dan menulis sebagai suatu produk, ketiga; struktur generik wacana tulis, keempat; perbedaan antara penulis terampil dan penulis yang tidak terampil, dan kelima; penerapan keterampilan menulis dalam proses pembelajaran. Hal ini sangat urgen diketahui oleh pembelajar keterampilan menulis, terlebih lagi dalam menulis Arab yang memiliki karakteristik tersendiri dibandingkan tulisan latin, baik dari segi penulisan huruf, penyambungan huruf, serta arah tulisan.

\section{Tujuan Pembelajaran Mahârah Kitâbah}

\footnotetext{
12 Zulhannan, Teknik Pembelajaran Bahasa Arab Interaktif, (Jakarta: Raja Grafindo Persada, 2014), 105.

${ }^{13}$ David Nunan, Research Method in Language Teaching, (Cambridge University Press, 1992), 86-90.
} 
Secara umum, tujuan pokok pengajaran maharah kitabah adalah menguasai pola dan struktur kalimat dalam bahasa Arab dan menggunakannnya secara tertulis untuk menyampaikan pesan atau tema tertentu yang dapat dipahami oleh penutur bahasa Arab. Dan lebih lanjut, Naqah dalam kitabnya merinci tujuan tersebut menjadi beberapa poin yang intinya adalah; ${ }^{14}$

a. Memahami dan mengaplikasikan konsep penulisan aksara Arab mulai dari aspek teknik (arah dan penyambungan), fonologis (huruf dan syakal), morfologis (derivasi kata), dan sintaksis (gramatisasi kata dalam kalimat) beserta implikasi maknaya.

b. Mampu menuangkan gagasan secara cepat dalam bentuk tulisan yang indah dan sesuai dengan kaidah penulisan dan tata bahasa Arab.

\section{Aspek-Aspek Pengajaran Mahârah Kitâbah}

Dalam pengajaran menulis, khususnya manulis bahasa Arab (maharah kitabah), setidaknya pengajaran menulis meliputi tiga aspek atau tahapan, yaitu pengajaran menulis dan merangkai huruf (khat), dikte (imla'), serta mengarang (insya'). Pengajaran khat mempunyai dua tujuan. Pertama; fisiologis, yakni membiasakan tangan untuk menulis dengan baik dan rapi, dan kedua; Psikologis, yakni meningkatkan kemampuan merangkai pikiran secara sistematis. Hal ini dapat diwujudkan apabila guru dapat memnerikan contoh yang tepat serta melatih siswanya secara intensif. 15

Adapun dikte (imla') dalam keterampilan menulis bahasa Arab, dapat dibagi menjadi 3 tahapan, pertama; reproduksi secara visual (imla' manqul), yakni menulis ulang kalimat, paragraf atau teks sambil melihatnya, kedua; reproduksi semi-visual (imla' mandhur), yaitu menulis ulang kalimat, paragraf atau teks tanpa melihat, namun sudah diperlihatkan dan dibacakan sebelumnya, ketiga; dikte secara utuh (imla' ikhtibariy), yaitu menulis apa yang dibaca oleh guru secara langsung. 16

\footnotetext{
14 Naqah, Thara'iq ........... 236.

15 Muhammad Shalih Samak, Fann Al Tadris li Al Tarbiyah Al Lughawiyyah, (Kairo: Dar Al Fikr Al 'Arabiy, 1998), 386.

16 Nayif Mahmud Ma'ruf, Khasha'is Al 'Arabiyyah wa Thara'iq Tadrisiha, (Beirut: Dar Al Nafa'is, 1998), 167.
} 
Demikian pula halnya mengarang (insya') dapat dibagi menjadi dua tahapan. Pertama, mengarang terstruktir/terikat (insya' muwajjah), merupakan tahapan penulisan yang lebih menitikberatkan pada penguasaan struktur gramatikal, misalnya berupa merubah kalimat, menjodohkan, mencocokkan, melengkapi kalimat, mengurutkan kalimat, menjawab pertanyaan, menceritakan gambar, dan sebagainya. ${ }^{17}$ Selanjutnya yang kedua; adalah mengarang bebas (insya' hurr) yang merupakan tahapan tertinggi dalan pembelajaran ketereampilan menulis, dan dapat dikategorikan dalam bentuk eksposisi, deskripsi, nsrasi, argumentasi, dan sebagainya.

Tahapan-tahapan pembelajaran menulis di atas merupakan urutan pembelajaran yang harus dilalui oleh pembelajar bahasa Asing, khususnya bahasa Arab. Hal ini dapat dijadikan sebagai rujukan bagi para pendidik bahasa Arab untuk mengembangkan keterampilan menulis peserta didik secara gradual dari tingkat dasar, menengah hingga tingkat lanjut.

\section{Penilaian Dalam Pengajaran Menulis}

Istilah penilaian dan evaluasi kadang kala dipergunakan secara tumpang tindih, padahal sejatinya kedua hal tersebut memiliki titik perbedaan. Penilaian adalah proses (kegiatan) sistematis dan berkesinambungan untuk mengumpulkan informasi tentang proses dan hasil belajar peserta didik dalam rangka mengambil keputusan berdasarkan kriteria tertentu. Sedangkan evaluasi lebih menekankan pada proses untuk menggambarkan peserta didik dan menimbangnya dari sedi nilai (value) dan arti, serta memiliki scope (ruang lingkup) dan teknis pelaksanaan yang lebih luas daripada kegiatan penilaian. 18

Evaluasi atau penilaian merupakan proses penting yang harus dilakukan oleh guru dalam kegiatan pembelajaran apapun, seperti halnya dalam pengajaran menulis. Kegiatan ini mempunyai peranan dan tujuan yang sangat penting yaitu sebagai sarana untuk mengetahui sejauh mana pencapaian kegiatan pembelajaran maupun siswa sendiri terhadap tujuan pembelajaran yang telah ditetapkan. Dengan begitu, dapat diambil langkah-langkah selanjutnya untuk memperbaiki dan meningkatkan kualitas

17 Muhammad Ali Al-Khuliy, Asalib Tadris al Lughah al Arabiyah, Cet 2, (Riyadh: Dar al Ulum, 1986), 138.

18 Zainal Arifin, Evaluasi Pembelajaran, Prinsip, Teknik, Prosedur, Cet-VI, (Bandung: Remaja Rosdakarya, 2014), 4-5. 
pembelajaran di masa yang akan datang. Diantara instrumen yang dapat dipakan dalam kegiatan evaluasi ini adalah, dengan bertanya secara langsung kepada siswa, memberikan PR, mengamati kegiatan siswa, dan tes (ujian). Dalam hal ini tes tersebut dapat berupa tes formatif maupun tes sumatif. 19

Dalam pengajaran menulis ada beberapa poin yang harus diperhatikan oleh guru sebagi tolak ukur kemampuan siswa dalam menulis yang sudah menjadi standar internasional dalam penilaian keterampilan menulis yaitu isi tulisan, organisasi penulisan, pilihan kata, struktur kebahasaan, dan pungtuasi/tanda baca. ${ }^{20}$ Sedangkan bentuk soal dalam tes keterampilan menulis secara umum dapat difokuskan dalam segi penguasaan kosakata dan penguasan struktur gramatikal. ${ }^{21}$ Secara khusus hal tersebut dapat berupa rekombinasi dan transformasi untuk mencari sinonom dan antonim kata serta struktur gramatikanlnya dalam kalimat, melengkapi, menjodohkan dan sebagainya. $^{22}$

Melihat hal itu, maka pendidik bahasa Arab idealnya harus mampu merancang konsep evaluasi terhadap peserta didiknya sesuai bidang maharah yang dipelajari dan ingin dinilai, apalagi dalam menulis Arab yang memiliki karakteristik dan kompleksitas yang tinggi. Hal ini mutlak membutuhkan kreativitas dan ketekunan agar dapat meningkatkan kualitas pembelajaran dan kemampuan pembelajarnya.

\section{METODE TOTAL PHYSICAL RESPONSE (TPR)}

\section{Sejarah Perkembangannya}

Metode TPR (Total Physical Response Method) adalah sebuah metode yang dikembangkan oleh James Asher, seorang profesor psikologi Universitas Negeri

\footnotetext{
${ }^{19}$ Tes Formatif adalah tes yang dilakukan untuk memperoleh umpan balik bagi guru/siswa serta sebagai bahan perbaikan konteks pembelajaran yang sedang berlangsung seperti tugas dan ulangan harian. Adapun tes sumatif digunakan untukmengukur derajat keberhasilan di akhir satuan pembelajaran seperti ujian akhir dan ujian nasional. Lihat Warsono dan Hariyanto, Pembelajaran Aktif Teori dan Assesment, (Bandung : Remaja Rosdakarya, 2014), 275.

${ }^{20}$ Holly Jacobs, ESL Compositoin Profile, (New York, 1981), 30.

${ }^{21}$ Fathi Ali Yunus, Al Marja' fi Ta'lim Al Lughah Al 'Arabiyyah li Al Ajanib min Al Nadhriyah ila Al Tathbiq, (Kairo: Maktabah Wahbah, 2003), 196.

${ }^{22}$ Muhammad Abd Al Khaliq, Ikhtibarat Al Lughah, (Riyadh: Jami'ah Al Malik Al Su'ud, 1989), 22.
} 
San Jose California. ${ }^{23}$ Metode ini merupakan salah satu metode pembelajaran untuk bahasa asing yang berlandaskan pada pendekatan naturalistik humanistik, seperti halnya dengan community language learning, suggestopedia, dan metode the silent way. Pendekatan humanistik menganggap siswa sebagai "orang sebagai satu kesatuan". ${ }^{24}$ Menurut Baharuddin, dalam teorinya, pendekatan humanis dalam pembelajaran lebih cocok diterapkan pada materi bersifat pembentukan kepribadian, hati nurani, perubahan sikap, dan analisis fenomena sosial, serta memberi perhatian khusus pada guru sebagai fasilitator. ${ }^{25}$ Dengan kata lain pengajaran bahasa tidak mengajarkan bahasa, tetapi juga membantu siswa mengembangkan diri mereka sebagai manusia.

Penekanan pada pemahaman (comprehension) dan menggunakan gerakan fisik dalam mengajar bahasa asing pada level pengenalan (introductory level) sebenarnya merupakan suatu tradisi yang dilakukan sejak lama dalam pembelajaran bahasa yang biasa disebut sebagai Action based teaching strategy atau English through Actions yang kemudian berkembang menjadi metode Total Physical Respons (TPR).

Metode ini telah dikembangkan selama lebih dari 20 tahun dan sudah terbukti keefektifannya ketika diuji cobakan untuk mengajar beberapa bahasa asing, seperti bahasa Inggris, Arab, jerman, Perancis, Jepang, Ibrani, dan Rusia. Karena itu, saat ini metode TPR (Total Physical Response Method) dianggap sebagai salah satu metode alternatif pembelajaran bahasa di berbagai lembaga pengajaran bahasa $\operatorname{asing.~}^{26}$

\section{Konsep Dasar Metode TPR}

Metode TPR (Total Physical Response Method) dipandang sebagai metode yang sesuai untuk mengajarkan bahasa asing untuk tahap awal dimana pembelajarannya lebih mengutamakan kegiatan langsung berhubungan dengan

${ }^{23}$ Douglas Brown, Usus Ta'allum al-Lughah wa Ta'limiha, Terj. Abduh Ar Rajiy, (Beirut: Dar an Nahdhah al Arabiyah, 1994), 196.

${ }^{24}$ Esa Nur Wahyuni Baharuddin, Teori Belajar dan Pembelajaran, (Yogyakarta: Ar Ruzz Media, 2007), 141.

${ }^{25}$ M. Thobroni, Belajar dan Pembelajaran, Teori dan Praktik, (Yogyakarta: Ar Ruzz Media, 2015), 134.

${ }^{26}$ James W. Asher, Fear of Foreign Language, (Psychologi Today, August 1981). www.tprworld.com 
kegiatan fisik (physical) dan gerakan (movement). ${ }^{27}$ Asher mengatakan bahwa semakin sering atau semakin intensif memori seseorang diberikan stimulasi maka semakin kuat asosiasi memori berhubungan dan semakin mudah untuk mengingat (recalling). Kegiatan mengingat ini dilakukan secara verbal dengan aktifitas gerak (motor activity). ${ }^{28}$

Dari sisi perkembangan, Asher melihat keberhasilan belajar bahasa kedua pada orang dewasa adalah sebagai proses yang paralel dengan pencapaian bahasa pertama anak. Dia mengklaim bahwa berbicara langsung kepada anak usia dini adalah merupakan suatu proses memberi perintah (command) dimana anak merespon secara fisik lebih dulu sebelum dia mampu menghasilkan respon secara verbal. ${ }^{29}$ Asher mamaparkan tiga prinsip utama keyakinannya tentang hakikat pemerolehan bahasa pertama. ${ }^{30}$

1) Kita harus menekankan pemahaman daripada produksi pada tahap awal pengajaran kedua tanpa meminta siswa untuk berlatih sendiri struktur bahasa sasaran.

2) Kita harus mematuihi prinsip di sini dan sekarang

3) Kita harus memberitahukan kepada pembelajar dengan meminta mereka melaksanakan perintah yang disampaikan dalam bentuk imperatif.

Lebih lanjut, Asher yang juga menyimpulkan bahwa peran faktor emosi sangat efektif dalam pembelajaran bahasa anak, artinya belajar bahasa dengan melibatkan permainan dengan bergerak yang bisa dikombinasikan dengan bernyanyi atau bercerita akan dapat mengurangi tekanan belajar bahasa seseorang. Dia percaya bahwa dengan keceriaan dalam diri siswa akan memberikan dampak positif bagi belajar bahasa siswa.

Pembelajaran bahasa bisa berlangsung ketika siswa mengamati tindakan dan melaksanakan tindakan tersebut. Karena tidak semua siswa dalam kelas dapat melaksanakan tindakan bersama-sama guru, maka siswa yang lain dalam kelas

\footnotetext{
${ }^{27}$ Jack. C. Theodore S. Rodgers Richard, Approaches and Methods in Language Teaching, Cambridge: Cambridge University Press, 1986), 87.

${ }^{28}$ Sri Utari Subyakto, Metodologi Pengajaran Bahasa, (Jakarta: Dirjen Pendidikan Tinggi DEPDIKBUD, 1998), 75.

${ }^{29}$ Brown, Usus Ta'allum 197.

${ }^{30}$ Furqanul Aziz, Pengajaran Bahasa Komunikatif Teori dan Praktek, Cet. 2, (Jakarta : Remaja Rosdakarya, 2000), 24.
} 
perlu mengamati tindakan-tindakan dan mendengarkan perintah-perintah. Cara belajar demikian didasarkan pemahaman bahwa para siswa yang mengamati tindakan-tindakan juga terlibat dalam pembelajaran. Asumsi lain tentang pembelajaran bahasa adalah bahwa stress dapat menghalangi kegiatan pembelajaran, semakin tinngi stress maka semakin rendah kualitas pembelajaran. Oleh karena itu, agar siswa berhasil dalam belajar bahasa sasaran, maka rasa stress harus dihilangkan karena mempunyai pengaruh negatif terhadap pelajaran dalam jangka panjang. Metode ini juga mendasarkan diri pada pemahaman tentang potensi fungsi otak kanan dan otak kiri. Aktivitas motorik, yang merupakan fungsi otak sebelah kanan, harus mendahului pengolahan bahasa yang merupakan potensi otak sebelah kiri. $^{31}$

Ada lima penekanan yang dikemukakan oleh Asher agar anak memiliki pemahaman bahasa yang disebut sebagai pendekatan pemahaman (Comprehension Approach) yaitu ${ }^{32}$ :

1) Kemampuan pemahaman diikuti dengan keahlian produktif dalam belajar bahasa (lisan dan tulisan).

2) Menunda pengajaran berbicara sebelum pemahaman anak sudah terbangun.

3) Keahlian didapat melalui mendengar yang ditransfer kepada keahlian lain (berbicara, membaca, dan menulis).

4) Pengajaran harus menekankan arti daripada bentuk dan

5) Pengajaran harus meminimalkan kadar stres pembelajar.

Dari pemaparan di atas, nampaknya Asher melihat penggabungan potensi otak kanan (melalui gerak fisik) dan potensi otak kiri (berbahasa) akan mampu memaksimalkan kemampunan anak didik. Kegiatan tersebut juga mampu menjadikan suasana kelas lebih rileks dengan pelibatan aktif semua komponen didalamnya sehingga sang guru seakan-akan berperan sebagai sutradara dan peserta didiknya sebagai aktor.

\section{Bentuk Pembelajaran di Kelas}

\footnotetext{
${ }^{31}$ Erta Mahyudin dan Aziz Fakhrurrozi, Pembelajaran Bahasa Arab, (Jakarta: Dirjen Pendis Kemenag RI, 2012.

${ }^{32}$ http://www.sil.org/lingualinks/languagelearning.htm
} 
Metode TPR (Total Physical Response) sangat membantu dalam mengenalkan kosa kata (mufradat) bagi penutur asing, khususnya bagi pembelajar pemula karena mereka hanya dituntut untuk menyimak dan meniru. Hal ini akan mengarahkan mereka pada pemahaman awal yang selanjutnya akan mendorong mereka untuk menggunakannya secara sederhana dalam bahasa lisan, dan terus berkembang lagi hingga menyentuh pada persoalan perubahan gramatikal. Keterampilan membaca dan menulis juga dapat diperkenalkan ketika kosakata tersebut sudah tidak asing lagi ditelinga mereka.

Dalam metode ini, guru memberi instruksi kepada siswa. Siswa tidak harus berbicara. Mereka hanya harus mengikuti perintah guru dalam bentuk respon fisik. Bila benar-benar menguasai mereka bisa memerintah kepada sesama temannya. Sebagai variasi, bentuk lain dari pembelajaran dengan metode ini misalnya ketika mengenalkan kata (berdiri) semua anak ikut berdiri sambil mendengarkan kata dan mengucapkan kata tersebut. Kemudian kita bisa menguatkan pengenalan kata tersebut sambil bernyanyi dan bergerak. ${ }^{33}$ Contoh aktifitas kelas melalui metode ini juga dapat dilihat pada kegiatan sebagai berikut : $:^{34}$

1) Para siswa duduk dalam posisi setengah lingkaran di sekeliling sang guru. Guru menyuruh mereka diam mendengarkan perintah-perintah, dan kemudian melakukan dengan tepat apa yang disuruh oleh guru. Para siswa didorong untuk memberikan respon secara tepat dan tanpa ragu-ragu. Misalnya, kalau guru memerintahkan siswa "maju” dengan mangatakan "تقلكم", maka para siswa maju dengan bersemangat.

2) Perintah-perintah lain misalnya: امش !، توقف!، اجلس !؛ ادخل !؛ اخرج ! akan dilaksanakan secara berurutan. Guru secara simultan melaksanakan perintah itu disertai oleh dua orang siswa yang duduk di sampingnya. Hal ini diulangi beberapa kali sampai para siswa yang duduk di sampingnya itu mantap benar dan para siswa secara individual menyatakan bahwa mereka ingin mencobanya sendiri tanpa gerakan guru sebagai model.

3) Berikutnya, perintah-perintah diperluas dengan kalimat lengkap, seperti :

\footnotetext{
${ }^{33}$ Aziez, Pengajaran Bahasa ............, 24.

${ }^{34}$ Fakhrurrozi, Pembelajaran ...............,126-127.
} 


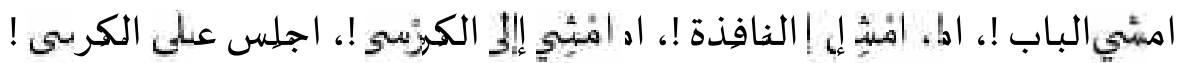

4) Setelah para siswa mempelajari lebih banyak kosakata dengan cara ini, maka hal-hal baru pun diperkenalkan, dan sang guru mulai menggunakan instruksi yang unik untuk menarik serta meningkatkan minat para siswa. Kata-kata benda dan kata-kerja (baru) diperkenalkan, misalnya :

$$
\begin{aligned}
& \text { إغسيل / امسيك ( يدك !؛ وجيَكَك!، شعرك!) } \\
& \text { خذل ( قلمك !، كتابك/ حقيبتك ) ثم ضع (على المكتب!، أمام الباب !، وراء الكرسى !) }
\end{aligned}
$$

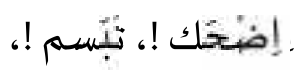

5) Berikutnya guru atau instruktur mengemukakan pertanyaan-pertanyaan sederhana yang dapat dijawab oleh siswa dengan gerakan, misalnya dengan cara menujuk. Misalnya:

$$
\begin{aligned}
& \text { أين الصيورة ؟ (الطالب يُشيرير إلى الصـورة) }
\end{aligned}
$$

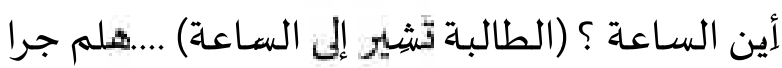

Sebagai variasi pula, setelah memberikan instruksi dan direspon oleh siswa, guru dapat memberikan beberapa pertanyaan sesuai dengan tingkat kesulitannya, misalnya : ${ }^{35}$

a) Pertanyaan yang jawabannya tidak menuntut siswa menggunakan kosakata baru, tetapi cukup membutuhkan pemahamannya saja, seperti :

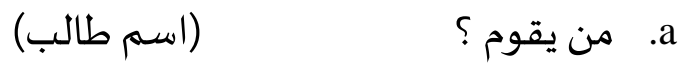

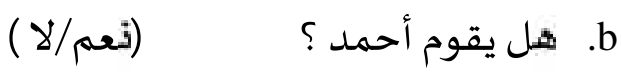

$$
\begin{aligned}
& \text { c. هل يقوم أحمد/زيد ؟ (ذعم/لا ) أو (اسم طالب) }
\end{aligned}
$$

b) Pertanyaan yang jawabannya menuntut siswa menggunakan kosakata baru. Dalam kondisi tertentu siswa juga boleh melakukan perubahan dalam jawabannya. Guru juga dapat merubah pertanyaan maupun situasinya yang memungkinkan siswa mendapatkan pengalaman baru seputar perubahan gramatikal, seperti :

$$
\begin{aligned}
& \text { (نعم، أحمد يقوم/لا، أحمد يجلس) } \\
& \text { a }
\end{aligned}
$$

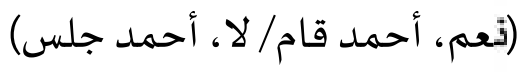

$$
\begin{aligned}
& \text { b }
\end{aligned}
$$

35 Young, Roberta. Using TPR to The Fullest. http//home.att.net/tpr/html 


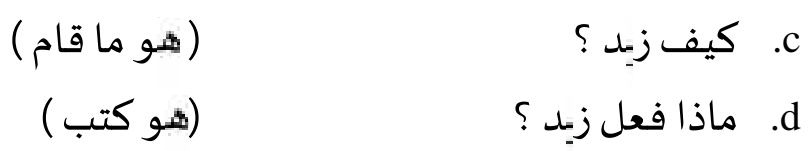

Untuk mengembangkan keterampilan menulis, dapat dilakukan aktifitasaktifitas tertentu, diantaranya :

a) Guru mempergunakan beberapa menit terakhir setiap pelajaran untuk menulis di papan tulis setiap butir kosakata baru dengan sebuah kalimat yang menggambarkan butir itu. Kemudian ia menyebutkan setiap butir dan meragakan kalimat itu. Para siswa menyimak dengan baik ketika guru membacakan bahan itu. Pada umumnya para siswa menyalin ekspresi-ekspresi tersebut dalam buku catatan mereka. Tidak ada terjemahan yang diberikan dalam bahasa siswa semua dalam bahasa sasaran.

b) Siswa menulis satu/lebih instruksi lalu menunjukkannya di depan kelas lalu yang lain memberikan respon.

c) Guru mengajukan pertanyaan-pertanyaan seperti di atas, kemudian siswa memberikan jawaban secara tertulis.

d) Guru mengajukan instruksi kepada siswa A, lalu siswa A merespon dan siswa lainnya diminta untuk menulis apa yang dilakukan siswa A

\section{Kelebihan dan Kelemahan Metode TPR}

Dari berbagai paparan di atas, Nampak bahwa metode TPR dapat dijadikan metode alternatif dalam pembelajaran maharah kitabah karena memiliki keunggulan dari segi kepraktisan pengaplikasiannya dan karakteristiknya yang mampu menjadikan suasana belajar lebih aktif, ceria, dan sangat sesuai bagi para pemula pembelajar bahasa asing dalam memperkaya mufradât (kosa kata) karena memaksimalkan potensi otak kanan dan kiri peserta didik.

Meskipun demikian, metode ini juga tidak luput dari berbagai hal yang menjadi titik lemahnya. Menurut penulis, diantara kekurangan dalam pelaksanaan metode ini adalah terbatasnya materi yang relevan dengan karakteristik metode yang didominasi dengan instruksi dan gerakan fisik. Selain itu karena seringnya diperlukan penguatan dan pengulangan serta kompleksnya aktifitas kelas, menjadikan metode ini menghabiskan lebih banyak waktu. Dan yang terakhir bahwa metode ini meninggalkan kesan teacher oriented yang begitu kental bila 
dibandingkan dengan berbagai pendekatan dan model pembelajaran terkini yang lebih student oriented.

\section{E. PENUTUP}

Maharah kitabah (keterampilan menulis) secara hierarkis menempati urutan keempat dalam pengajaran keterampilan berbahasa. Urutan ini menurut sebagian kalangan disebabkan karena tingkat kesulitan dan kompleksitas kemampuan yang dibutuhkan agar bisa dikatakan mahir menulis. Terlebih lagi menulis dalam bahasa Arab yang memiliki teknik dan karakteristik tersendiri. Karena itu dibutuhkan kreatifitas dan inovasi guru bahasa arab dalam mengajarkannya kepada peserta didik. Salah satu metode alternatif untuk melatih dan meningkatkan Mahârah Kitâbah peserta didik adalah metode Total Physical Response (TPR). Terlepas dari kelebihan dan kekurangannya, metode ini menawarkan suasana pembelajaran yang unik dan berkesan ketika diimplementasikan dengan benar oleh pendidik ketika mengajar bahasa Arab, khususnya keterampilan menulis. 


\section{DAFTAR PUSTAKA}

Muhammad Shalih Al Syantha, Al Maharat Al Lughawiyyah Madkhal ila Khasha'isi Al Lughah Al 'Arabiyyah wa Fununiha, Ha'il: Dar Al Andalus li Al Nasyr wa Al Tauzi', 1996.

Muhammad Ali Al-Khuliy, Asalib Tadris al Lughah al Arabiyah, cet 2. Riyadh: Dar al Ulum, 1986.

James W. Asher, Fear of Foreign Language, (Psychologi Today, August), www.tprworld.com, 1981.

Furqanul Aziz, Pengajaran bahasa Komunikatif Teori dan Praktek, Cet 2. Jakarta : Remaja Rosdakarya, 2000

Aziz Fakhrurrozi, Erta Mahyudin, Pembelajaran Bahasa Arab, Jakarta : Dirjen Pendis Kemenag RI, 2012.

Yus Badudu, Mahir Berbahasa Indonesia, Jakarta : Gramedia, 1990.

Baharuddin, Esa Nur Wahyuni, Teori Belajar dan Pembelajaran, Yogyakarta : Ar Ruzz Media, 2007.

Douglas Brown, Usus Ta'allum al-Lughah wa Ta'limiha, terj. Abduh Ar Rajiy. Beirut: Dar an Nahdhah al Arabiyah, 1994.

M. Soenardi Djiwandono, Tes Bahasa dalam Pengajaran, Bandung: Penerbit ITB, 1996.

Ahmad Fuad Effendi, Metodologi Pengajaran Bahasa Arab, Malang: Misykat.

http://www.sil.org/lingualinks/languagelearning.htm, 2005.

Hamadah Ibrahim, Al Ittijahat Al Mu'ashirah fi Tadris Al Lughah Al 'Arabiyah wa Al Lughah Al Hayyah Al Ukhra lighair Al Nathiqin biha, Kairo: Dar Al Fikr Al 'Arabiy, 1987.

Holly Jacobs, ESL Compositoin Profile, New York, 1981.

Hilmi Khalil, Muqaddimah li Dirasah 'Ilmi al Lughah, Kairo: Dar al Ma'rifah al Jama'iyyah, 2000. 
M. Thobroni,. Belajar dan Pembelajaran, Teori dan Praktik, Yogyakarta: Ar Ruzz Media, 2015.

Nayif Mahmud Ma'ruf, Khasha'is Al 'Arabiyyah wa Thara'iq Tadrisiha, Beirut : Dar Al Nafa'is, 1998.

Muhammad Abd Al Khaliq Muhammad, Ikhtibarat Al Lughah, Riyadh: Jami'ah Al Malik Al Su'ud, 1989.

Mahmud Kamil Naqah, Thara'iq tadris al-Lugah al-'Arabiyyah lighair al-Nathiqin biha, Rabat: ISESCO, 2003.

David Nunan, Research Method in Language Teaching, Cambridge University Press, 1992.

Ahmad Ibrahim Qindil, Ususu Thuruq Al Tadris, Dar Al Kutub, 1995.

Richard, Jack. C. Theodore S. Rodgers, Approaches and Methods in Language Teaching, Cambridge : Cambridge University Press, 1986.

S. Riyono, Teknik Belajar Mengajar dalam CBSA, Jakarta : Rineka Cipta, 1991.

Rusydi Ahmad Thu'aimah dan Mahmud Kamil Naqqah, Thara'iq Tadris Al Lughah Al 'Arabiyyah Li Ghair An Nathiqin Biha, Rabat : Isesco, 2003.

Samak, Muhammad Shalih, Fann Al Tadris li Al Tarbiyah Al Lughawiyyah, Kairo: Dar Al Fikr Al 'Arabiy, 1998.

Subyakto, Sri Utari, Metodologi Pengajaran Bahasa, Jakarta: Dirjen Pendidikan Tinggi DEPDIKBUD, 1998.

Tu'aimah, Rusdy Ahmad. Ta'lim al-'Arabiyyah lighair al-Nathiqin biha Manahijuhu wa Asalibuhu. Rabat: ISESCO. 1989.

Warsono, Hariyanto, Pembelajaran Aktif Teori dan Assesment (Bandung : Remaja Rosdakarya, 2014.

Roberta Young, Using TPR to The Fullest, http//home.att.net/tpr/html

Fathi Ali Yunus, Al Marja' fi Ta'lim Al Lughah Al 'Arabiyyah li Al Ajanib min Al Nadhriyah ila Al Tathbiq, Kairo: Maktabah Wahbah, 2003.

Zainal Arifin, Evaluasi Pembelajaran, Prinsip, Teknik, Prosedur, Cet-VI, Bandung : Remaja Rosdakarya, 2014.

Zulhannan, Teknik Pembelajaran Bahasa Arab Interaktif, Jakarta: Raja Grafindo Persada, 2014. 